\title{
STRATEGI KOMUNIKASI UNTUK MENCIPTAKAN KAWASAN PANTAI YANG BERSIH DARI SAMPAH (STUDI KASUS TAPLAU PADANG)
}

\author{
YUNI CANDRA ${ }^{1}$, SUSI EVANITA ${ }^{2}$ \\ Program Doktoral Kajian Lingkungan dan Pembangunan Fakultas Ekonomi ${ }^{1}$, \\ Dosen Pascasarjana Universitas Negeri Padang ${ }^{2}$
}

\begin{abstract}
Waste management so far has not been optimally carried out because it is not in accordance with environmentally sound waste management methods and techniques so that it has a negative impact on the cleanliness of the coastal area and the environment becomes dirty. The waste problem has become a national problem, so that its management needs to be carried out in a comprehensive and integrated manner from upstream to downstream in order to provide economic benefits, be healthy for the community, and safe for the environment, and can change people's behavior. This can be seen from the conditions in Taplau Padang that waste management is still not running optimally. The condition of waste in coastal tourist areas in general has not been managed optimally even though it already has waste management components. In fact, many cleaning managers face problems and obstacles that result in services that are not in accordance with the technical provisions and expectations of tourists. Taking into account the condition of the waste, the activities of throwing garbage to the seaside or littering have been going on for a long time by the people around Taplau Padang. Because some of the garbage has mixed with the ground and a lot of it settles on the beach and around the beach. As a result, there is a view that is not good to see and be seen by tourists who are in Taplau Padang.
\end{abstract}

Keywords: Communication Strategy, Coastal Area, Padang, Clean.

Abstrak: Pengelolaan sampah selama ini belum optimal dilakukan karena belum sesuai dengan metode dan teknik pengelolaan sampah yang berwawasan lingkungan sehingga menimbulkan dampak negatif terhadap kebersihan kawasan pantai dan lingkungan menjadi kotor. Persoalan sampah telah menjadi masalah nasional, sehingga dalam pengelolaannya perlu dilakukan secara komprehensif dan terpadu dari hulu ke hilir agar memberikan manfaat secara ekonomi, sehat bagi masyarakat, dan aman bagi lingkungan, serta dapat mengubah perilaku masyarakat. Hal ini dapat dilihat dari kondisi yang ada di Taplau padang bahwa pengelolaan sampah masih belum berjalan secara optimal. Kondisi persampahan kawasan pantai pada umumnya belum terkelola secara maksimal walaupun sudah memiliki komponen-komponen pengelolaan sampah. Kenyataannya banyak pengelola kebersihan menghadapi masalah dan kendala yang mengakibatkan pelayanan yang tidak sesuai dengan ketentuan teknis dan harapan dari wisatawan. Memperhatikan kondisi sampah tersebut, aktifitas membuang sampah ke tepi laut atau membuang sampah sembarangan sudah berlangsung lama oleh masyarakat di sekitar Taplau Padang. Karena sebagian sampahnya sudah bercampur dengan tanah serta banyak mengendap di pantai dan disekitar tepi pantai. Akibatnya, terdapat pemandangan yang kurang baik untuk dilihat dan dipandang oleh wisatawan yang berada di Taplau Padang.

Kata Kunci: Strategi Komunikasi, Kawasan Pantai, Padang, Bersih. 


\section{A. Pendahuluan}

Indonesia merupakan Negara kepulauan yang mempunyai beragam kebudayaan dimilikinya. Lingkungan pantai merupakan suatu kawasan yang spesifik, dinamis, kaya keanekaragaman hayati dan banyak manfaatnya bagi masyarakat. Kebersihan pantai dari sampah merupakan salah satu pertimbangan bagi wisatawan untuk mengunjunginya, (Darmawi, 2017). Faktor yang menyebabkan permasalahan sampah di Indonesia semakin rumit adalah meningkatnya taraf hidup masyarakat, yang tidak disertai dengan keselarasan pengetahuan tentang persampahan dan juga partisipasi masyarakat yang kurang untuk memelihara kebersihan dan membuang sampah pada tempatnya, (Syam, 2014).

Pencemaran lingkungan mempengaruhi sektor wisata yang akan mengakibatkan berkurangnya kualitas ekologis dan jumlah kunjungan wisatawan di destinasi wisata tersebut (Rahmawati, 2009). Kegiatan wisata berjalan tidak mempertimbangkan keberlanjutan sumber daya. Untuk mempertahankan keseimbangan alam dan keberlanjutan sumber daya, diperlukan penataan kawasan dengan prinsip konservasi. Keberhasilan pengelolaan dan pengembangan kawasan wisata merupakan hasil kerja sama antara stakeholder, yaitu pemerintah, swasta dan masyarakat. Dimana, pengembangan ekowisata melibatkan berbagai pihak seperti pengunjung, sumber daya alam, pengelola, masyarakat lokal, kalangan bisnis termasuk biro perjalanan, pemerintah dan LSM (Yuliani, 2017).

Membangun kesadaran masyarakat tidak semudah membalikkan telapak tangan. Perlu kerja sama dari semua pihak, baik masyarakat, pemerintah maupun pihak ketiga sebagai pendukung. Diperlukan waktu yang cukup lama untuk membangun kesadaran itu. Diperlukan pula contoh dan teladan yang positif serta konsistensi dari pihak pengambil kebijakan di suatu wilayah tertentu. Kegiatan sosialisasi secara langsung tentang pengelolaan sampah dapat mendorong partisipasi masyarakat dalam hal pengelolaan persampahan (Rizal, 2011). Pengelolaan sampah tidak hanya dilihat dari aspek teknis saja, akan tetapi juga non teknis seperti bagaimana melibatkan masyarakat penghasil limbah agar ikut berpartisipasi secara aktif atau pasif dalam aktivitas penanganan sampah sejak ditimbulkan sampai dengan pembuangan akhir, (Gunungkidul, 2018).

Hal ini menjadi salah satu faktor yang menyebabkan masyarakat disekitar destinasi wisata Taplau Padang masih terdapat masyarakatnya membuang sampah ketepi laut dan danau yang ada disekitarnya. Secara kasat mata dapat disaksikan tumpukan sampah yang sebagian besarnya sampah rumah tangga, sampah dari para pedagng di Taplau Padang. Terlihat miris, bahwa pengelolaan sampah yang baik oleh masyarakat masih rendah. Terlebih lokasi tumpukan sampah ini berada di objek wisata yang menjadi icon wisata kota Padang. Berbagai persoalan lingkungan terjadi ketika terjadi hujan lebat, tumpukan sampah akan menjadi pemandangan yang tidak dapat di elakkan di taplau Padang. 

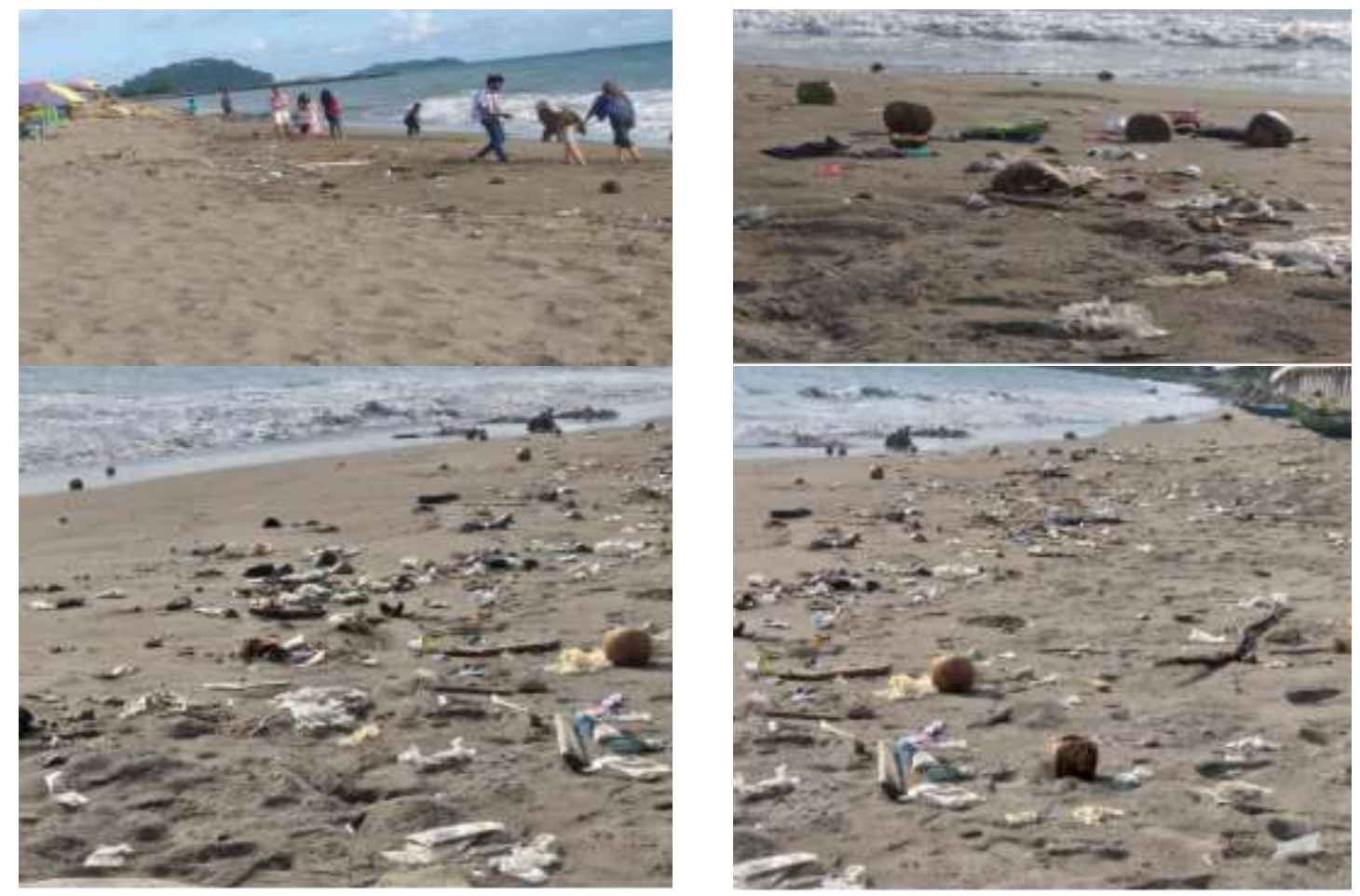

Gambar 1.Tumpukan sampah dari sampah rumah tangga, dagangan dan limbah rumah makan (foto di ambil 3 juni 2021).

Masalah sampah mutlak harus ditangani secara bersama-sama antara pemerintah, dan masyarakat itu sendiri. Oleh karena itu dibutuhkan kesadaran dan komitmen bersama menuju prubahan sikap, perilaku dan etika yang berbudaya lingkungan. Destinasi wisata perlu dijaga kelesatariannya dan kebersihan lingkungan agar terlihat bersih dan sedap dipandang mata, tidak bau yang tidak sedap dan jika tidak diatur dengan baik akan menimbulkan banyak permasalahan. Persoalan sampah merupakan persoalan pelik. Dalam kehidupan sehari-hari. Sampah sudah menjadi pemandangan yang dianggap biasa padahal hal ini merupakan persoalan serius karena menyangkut hajat hidup orang banyak di bidang kesehatan, hukum, dan sosial. Sebagian masyarakat masih kurang peduli pada kebersihan lingkungan seakan-akan sampah dianggap persoalan kecil, dan tidak terlalu penting untuk diprioritaskan sehingga muncul kesan jika persoalan sampah di Indonesia adalah persoalan yang tidak terselesaikan.

Sampah yang menumpuk, menimbun, atau tercampur antara organik dan non organik mempunyai potensi pencemaran dan merusak lingkungan kesehatan. Namun kesadaran akan bahaya sampah ini masih memprihatinkan bahkan berkembang di sebagian masyarakat kalau Pemerintah atau lembaga non pemerintah lainnya tidak peduli atau tidak mempunyai program unggulan dalam mengentaskan persoalan sampah. Sosialisasi maupun komunikasi penting untuk dilakukan dalam upaya pelestarian lingkungan dan tidak membuang sampah ke laut diperlukan strategi komunikasi yang sesuai untuk mencapai tujuan menumbuhkan kesadaran, diantaranya melalui komunikasi dan bahasa positif. Pendekatan komunikasi dengan bahasa posistif ini diharapkan dapat meningkatkan pemahaman dan menumbuhkan kesadaran warga di sekitar destinasi Taplau padang dapat mengelola sampah dengan baik dan tidak lagi membuang sampah ke sembarangan tempat disekitar destinasi wisata Taplau Padang. 
Dari pemaparan tersebut di atas dapat dicermati bahwa kondisi sampah di destinasi wisata Tapalu padang perlu mendapat perhatian dari stakeholders yang ada agar kebersihan pantai dapat terjaga dengan baik. Dan tidak mencemari dan memberikan dampak buruk di pada sektor wisatawan di taplau padang ini. Pemahaman masyarakat sendiri tentang pengeloaan sampah masih sangat rendah. Sampah rumah tangga termasuk dalam penyumbang sampah terbesar. Begitupun sampah yang dibuang disekiran pantai dan ke laut oleh para pedagang. Hal ini menjadi perhatian penulis untuk membuat makalah ini agar lebih fokus dalam mengkaji strategi komunikasi mengendalikan dan mengelola sampah oleh masyarakat. Dari latar belakang permasalahan yang diuraikan diatas, maka dapat dirumuskan permasalahan yaitu: "Bagaimana strategi komunikasi untuk menciptakan lingkungan yang bersih"?

\section{B. Metodologi Penelitian}

Metodologi penelitian yang dipakai disesuaikan dengan kebutuhan penelitian ini, yang nantinya akan meneliti tentang komunikasi terhadap kesadaran masyarakat dalam pelaksanaan pengelolaan sampah di Taplau Padang dan peran masyarakat dalam pengelolaan sampah Taplau Padang.

\section{Hasil dan Pembahasan}

Permen Nomor 33 Tahun 2010 Tentang Pedoman Pengelolaan Sampah, mendefenisikan sampah adalah sisa kegiatan sehari-hari manusia dan proses alam yang berbentuk padat yang terdiri dari sampah rumah tangga maupun sampah sejenis sampah rumah tangga. Sampah rumah tangga yaitu sampah yang berasal dari kegiatan sehari-hari dalam rumah tangga yang sebagian besar terdiri dari sampah organik, tidak termasuk tinja dan sampah spesifik.

Sampah pada dasarnya merupakan suatu bahan yang terbuang atau dibuang dari sumber hasil aktivitas manusia maupun proses-proses alam yang tidak mempunyai nilai ekonomi, bahkan dapat mempunyai nilai ekonomi yang negatif karena dalam penggunaannya baik untuk membuang atau membersihkannya perlu biaya yang cukup besar. Sampah adalah sebagian dari sesuatu yang tidak dipakai, tidak disenangi, atau sesuatu yang harus dibuang, yang umumnya berasal dari kegiatan yang dilakukan oleh manusia.

Sampah merupakan salah satu masalah penyebab penyakit tidak seimbangnya lingkungan hidup, yang umumnya terdiri dari komposisi sisa makanan, daun-daun, plastik, kain bekas, karet, tanah dan lain-lain. Sedangkan Nugroho (2007) berpendapat bahwa sampah adalah bahan sisa atau produk sampingan dari kegiatan manusia yang sudah tidak berguna dan kemudian dibuang (waste), sehingga bias menyebabkan gangguan estetika, kerusakan dan pencemaran lingkungan, atau mengandung unsur berbahaya, serta kesehatan kehidupan manusia dan lingkungan.

Terjadinya kawasan pantai yang bersih, aman dan nyaman merupakan faktorfaktor yang sangat mempengaruhi tingkat kunjungan wisatawan, baik wisatawan lokal, dosmestik maupun wisatawan manca negara. Isu lingkungan yang kotor, pengelolaan sampah yang tidak tepat, kawasan pantai yang sudah mulai kotor akan menyebabkan ketidaknyaman bagi wisatawan untuk berada di destinasi wisata tersebut.

Kenyataan ini mengindikasikan bahwa upaya meningkatkan kesadaran dan kepedulian masyarakat terhadap lingkungan perlu dilakukan secara sinergis. Banyak 
faktor yang dapat mempengaruhi tingkat kesadaran masyarakat. Kita harus sadar jika kita tahu, mengerti, insyaf, dan yakin tentang kondisi tertentu. Kesadaran masyarakat lahir dari masyarakat itu sendiri yang lahir dari kebiasaan dalam masyarakat, dipengaruhi oleh lingkungan, peraturan- peraturan dan peranan pemerintahnya.

Berdasarkan pendapat tersebut, maka peran pemerintah dan aturan-aturannya menjadi penting sebagai pendekatan utama membangun kesadaran masyarakat. Apabila diberlakukan aturan sakaligus menyediakan fasilitasi bagi masyarakat maka secara tidak langsung akan membentuk dan mengubah pola pikir masyarakat terhadap lingkungan tempat tinggalnya. Faktor ketersediaan sarana dapat menunjang aksi dalam mewujudkan perilaku sadar lingkungan. Hal ini dilihat dari nilai indeks perilaku peduli lingkungan untuk indikator pengelolaan sampah memperoleh nilai skor rendah yang mana responden beralasan bahwa perilaku ini timbul karena tidak ada fasilitas. Selain itu, kegiatan sadar lingkungan (memilah sampah) dipandang tidak menguntungkan secara ekonomi.

Oleh karena itu perlu perhatian yang cukup serius bagi bagi masyarakat di sekitar destinasi wisata taplau padang berbenah terkait dengan permasalahan sampah tersebut antara lain dengan cara menanamkan kesadaran dan kepedulian masyarakat maupun keterlibatan secara langsung dalam pengkondisian lingkungan. Lingkungan bersih yang dimaksud disini adalah lingkungan yang memiliki pengelolaan sampah dan pengolahan air limbah yang lebih baik.

Menurut (Sahil, 2016), jumlah sampah ini setiap tahun terus meningkat sejalan dan seiring meningkatnya jumlah penduduk dan kualitas kehidupan masyarakat atau manusianya dan disertai juga kemajuan ilmu pengetahuan teknologi yang menghasilkan pula pergeseran pola hidup masyarakat yang cenderung konsumtif. Sampah plastik yang dibuang secara sembarangan selain merusak estetika, sampah plastik juga merusak lingkungan dan berdampak negatif pada kesehatan, dari sampahsampah plastik yang menumpuk misalnya di sungai bisa menyebabkan banjir, dan mencemari air laut. Untuk itu sampah-sampah yang dihasilkan harus dikelola dengan tepat. Caranya dengan membuang sampah pada tempatnya. Pisahkan antara sampah organik dan anorganik, jika mampu ubah sampah menjadi barang yang nilai tambah.

Menurut (Sulistiyorini, 2015), partisipasi masyarakat dalam pengelolaan sampah dapat meningkatkan kesadaran masyarakat akan pentingnya kebersihan lingkungan yang hijau, bersih dansehat serta menguatkan inisiatif masyarakat dalam menjaga, memelihara dan meningkatkan fungsi lingkungan. Disampingitu, kemampuan masyarakat berkontribusi dalam pengelolaan sampah juga akan sangat tergantung kepada pendapatan masyarakat.

Menurut (Hardiana, 2018), Kebersihan merupakan suatu keadaanyang tampak bersih, sehat dan indah.Lingkungan yang bersih merupakan hakdasar setiap manusia dalam memperolehkesehatan dalam penghidupannya. Segalasesuatu yang terjadi di lingkungan akanberpengaruh terhadap kelangsungan kehidupan dan kesejahteraan manusia dan makhluk hidup lainnya. Dalam menjaga lingkungan yang bersih perlu kesadarandiri manusia sebagai makhluk yang memiliki pikiran. (Sulistiyani, 2017), masyarakat belum sepenuhnya siap berperan sebagai subjek pembangunan, khususnya dalam pengelolaan sampah. Tindakan strategis berkelanjutan dalam rangka pembangunan manusia dan solusi alternatif untuk mengatasi permasalahan sampah dapat ditempuh melalui pemberdayaan. 


\section{Strategi Komunikasi Untuk Menciptakan kawasan Yang Bersih Dari Sampah}

Untuk mangatasi persoalan sampah yang ada di Taplau Padang perlu dilakukan komunikasi yang efektif, sehingga persoalan sampah tersebut dapat teratasi dengan baik. Walau Permasalahan sampah sebenarnya bukan menjadi kewajiban yang dilakukan oleh pemerintah dan segelintir lembaga saja akan tetapi juga merupakan kewajiban seluruh masyarakat dan memerlukan wujud nyata dan komitmen yang kuat dari seluruh masyarakat yang berada di sekitar destinasi wisata Taplau padang.

Strategi komunikasi untuk menciptakan kawasan yang yang bersih dari sampah di Taplau padang, diharapakan dapat memberikan efek pada perubahan sikap maupun perilaku masyarakat untuk menjadi lebih cinta lingkungan, terampil dalam mengolah dan mendaur ulang sampah. Maka dari itu, untuk lebih mengetahui bagaimana strategi komunikasi dapat di uraikan, diantaranya:

a. Pengenalan Sasaran Komunikasi

Yang menjadi sasaran komunikasi adalah masyarakat yang berada di sekitar Taplau Padang yang dapat dijadikan informan.

b. Tujuan Pesan Komunikasi Yang Akan Dilakukan

Pesan komunikasi mempunyai tujuan tertentu untuk meningkatkan kesadaran masyarakat untuk menciptakan lingkungan yang bersih di Taplau padang. Untuk mencapai tujuan tersebut perlu di perhatikan perumusan pesannya yang akan dilakukan. Adapun pesan yang disampaikan dirumuskan tiga bagian, yaitu : isi pesan, struktur pesan, dan format pesan. Isi pesan, komunikator harus memikirkan apa yang akan dikatakan kepada masyarakat sasaran untuk menghasilkan respons yang diinginkan. Ada tiga daya tarik yang dapat dibedakan: Daya tarik rasional untuk menarik minat masyarakat agar mau bertangggung jawab terhadap lingkungan, sehingga tercipta lingkungan yang bersih dari sampah. Daya tarik emosional adalah untuk memotivasi masyarakat agar terdorong untuk menghabiskan waktu luang mereka untuk hal yang bermanfaat dan menumbuhkan kesadaran lingkungannya. Sedangkan daya tarik moral diarahkan ke perasaan masyarakat bahwa masalah sampah ini bukan hanya tanggung jawab pemerintah akan tetapi tanggung jawab semua lapisan masyarakat.

Stuktur pesan diharapkan dapat membangkitkan perhatian masyarakat (attention), mampu membangkitkan kebutuhan masyarakat terhadap isi pesan yang disampaikan oleh komunikator (needs), memberikan kepuasan terhadap kebutuhan masyarakat (satisfaction), mampu memberikan gagasan yang baik oleh komunikator (visualization), dan menegaskan gagasan agar audiens bertindak (action). Format pesan yang perlu dilakukan adalah memberikan perhatian pada nada suara, melakukan pemilihan kata yang tepat, dan bahasa tubuh yang baik.

c. Menetapkan metode

Dalam dunia komunikasi metode dapat dilihat dari dua aspek yaitu menurut cara pelaksanaannya dan menurut bentuk isinya. Hal tersebut dapat diuraikan lebih lanjut, bahwa aspek pertama direalisasikan dalam dua bentuk, yaitu metode redundancy (repetition / di ulang-ulang) dan canalizing (mendalam). Sedang yang kedua (menurut bentuk isinya) dikenal metode seperti informatif, persuasif, edukatif, dan kursif.

d. Seleksi dan Penggunaan Media Komunikasi

Setelah mengetahui kelompok sasaran komunikasi yang diinginkan dan langkah selanjutnya adalah menetapkan tujuan dari pesan, pemilihan media komunikasi 
merupakan faktor yang perlu dilaksanakan yaitu melakukan pemilihan media komunikasi yang tepat sebagai alat untuk menyalurkan ide, untuk mendapatkan feedback dari masayarakat menjadi suatu keharusan sehingga dapat menjangkau sasaran komunikasi masyarakat secara lebih luas, juga memjadi fungsi sosial yang dapat dijadikan alat penerangan bagi masyarakat. Adapun media komunikasi yang dipakai adalah: Media tatap muka dilakukan dengan cara melakukan sosialisasi langsung kepada masyarakat yang menjadi sasaran. Media tatap muka lebih persuasif dan efektif dibandingkan dengan media massa karena memungkinkan untuk berbicara dan memberikan umpan balik. Akan tetapi media tatap muka ini daya jangkau dan kecepatan pesannya terbatas.

d. Peran Komunikator Dalam Menyampaikan Pesan

Peranan komunikator dalam menyampaikan pesan komunikasi sangatlah berpengaruh dalam meyakinkan masyarakat sasaran. Adapun peranan komunikator yang perlu menjadi perhatian sebelum melakukan sosialisasi pada masyarakat sasaran, agar kelancaran komunikasi berjalan dengan lancar antara lain:

1. Daya tarik sumber

Daya tarik sumber merupakan karakteristik yang ikut menentukan keberhasilan upaya persuasi dalam penyampaian pesan. Apabila sumber dinilai menarik oleh penerima, maka upaya persuasi akan lebih cepat berhasil karena adanya proses identifikasi dalam diri pihak penerima.

Pemuka masyarakat dianggap dapat mempengaruhi kelompok masyarakat karena memiliki teladan tersendiri bagi masyarakat. Seringkali masyarakat akan meminta saran kepada pemuka masyarakat,pada umumnya masyarakat lebih mendengar himbauan yang disampaikan oleh pemuka masyarakatnya. Komunikasi antar pribadi antara masyarakat dengan pemuka memberikan kontribusi yang penting bagi keberhasilan sosialisasi.

2. Kredibilitas sumber

Kredibilitas merujuk pada suatu kondisi dimana informan dinilai layak untuk berbagi pengalaman, keahlian atau pengalaman yang relevan dengan pesan yang disampaikannya, sehingga pihak penerima pesan dapat percaya bahwa pesan yang disampaikannya adalah objektif.

Dari apa yang sudah diuraikan diatas, dapat menjawab pertanyaan "Who Says What In Which Channel To Whom With What Effect? (siapa mengatakan apa dengan cara apa kepada siapa dengan efek bagaimana)" sebagaimana yang dikemukanan oleh (Cangara 2003). sehingga dapat dilihat dari faktor penghambag dan faktor pendukung dari hasil pengamatan yang dilakukan.

\section{Faktor Penghambat}

1. Masyarakat yang kurang mau memperhatikan kebersihan akan sampah dan kurang memahami masalah sampah yang ada di Taplau Padang, buang sampah sembarangan dan sebagainya.

2. Kesadaran masyarakat dan partisipasi masyarakat khususnya pedagang kaki lima masih sangat rendah untuk mengelola sampah yang di hasilkan dari kegiatan yang mereka lakukan.

3. ketersedian tong sampah yang berada di sekitar Taplau padang masih kurang memadai dengan kondisi taplau Padang saat ini.

\section{Faktor Pendukung}

Adapaun yang menjadi faktor pendukung nya adalah ; 
1. Masyarakat welcome pada saat dilakukan sosialisasi pentingnya kebersihan lingkungan pantai untuk menciptatakan kawasan pantai yang bersih.

2. Adanya dukungan dari tokoh masyarakat setempat saat melakukan sosialisasi di sekitar Taplau Padang.

Hasil pengamatan yang dilakukan tentang menciptakan kawasan panyai yang bersih dari sampah sudah cukup baik tetapi masih belum efektif. Hal ini disebabkan oleh banyaknya masyarakat di Taplau Padang masih belum menjalankan kegiatan menjaga kebersihan pantai secara baik. Selain itu minimnya dan kurang meratanya sosialisasi untuk pengelolaan sampah dengan baik yang dilakukan oleh dinas terkait menyebabkan hanya pada wilayah tertentu yang mengetahui dan paham tentang penanggulangan sampah tersebut.

\section{Penutup}

Strategi Komunikasi yang dijalankan secara efektif menjadi faktor utama dalam menciptakan kawasan yang bersih, bebas dari sampah. Komunikasi yang sukses dan efektif berasal dari pelaksanaan proses komunikasi yang dijalankan oleh komunikator. Orang-orang yang terlibat akan meningkatkan keterampilan komunikasi mereka jika mereka mengikuti proses komunikasi, dan tinggal jauh dari hambatan yang berbeda. Telah terbukti bahwa individu yang memahami proses komunikasi akan berkembang menjadi komunikator yang lebih efektif, dan komunikator yang efektif memiliki kesempatan lebih besar untuk menjadi sukses. Oleh karena itu kita harus menggunakan model-model komunikasi yang pas dalam berkomunikasi. Proses strategi komunikasi yang dilakukan dapat memperhatikan beberapa aspek yaitu prinsip yang dijadikan landasan dalam melakukan komunikasi, tahap-tahap berlangsungnya proses komunikasi, dan penggunaan teknik serta strategi yang tepat dalam berkomunikasi. Akan tetapi proses komunikasi tidak akan berhasil jika komunikator tidak mampu mengatasi hambatan-hambatan yang terjadi dalam komunikasi tersebut. Dengan menerapkan aspek-aspek yang telah disebutkan sebelumnya, maka komunikator dapat mencapai tujuan komunikasi secara efektif. Perencanaan dan pengembangan pesan komunikasi perlu dilakukan dalam komunikasi, karena pesan dalam komunikasi merupakan unsur yang sangat berperan penting dalam proses berkomunikasi. Kemudian pengimplementasian komunikasi dapat dikaitkan dengan hubungan masyarakat dalam kegiatannya yang memerlukan adanya proses persuasi untuk mempengaruhi khalayak.

\section{Daftar Pustaka}

Cangara, Hafied. 2003. Pengantar Ilmu Komunikasi (Cetakan Keempat). Jakarta : PT. RajaGrafindo Persada.

Gunung kidul, K. (2018). Partisipasi Pelaku Usaha Pariwisata dalam Pengelolaan Sampah di Pantai Pulang. 2(2), 122-133.

Hardiana, D. ( 2018). Perilaku Masyarakat Dalam Menjaga Kebersihan Lingkungan Lingkungan Pantai Kecamatan Sasak Ranah Pasisie Kabupaten Pasaman Barat. Jurnal Buana 2 (2).

Rahmawati, A. (2009). Studi Pengelolaan Kawasan Pesisir Untuk Kegiatan Wisata Pantai (Kasus Pantai Teleng Ria Kabupaten Pacitan, Jawa Timur).

Rizal M. (2011). Analisis Pengelolaan Persampahan Perkotaan. Studi Kasus Pada Kelurahan Boya. 
Sahil, J., Muhdar, M. H. I., Rohman, F \& Syamsuri, I. (2016). Sistem Pengelolaan dan Upaya Penanggulangan Sampah di Kelurahan Dufa-Dufa Kota Ternate. Jurnal Bioedukasi 4 (2).

Sulistyorini, N. R., Darwis, R. S \& Gutama, A. S. (2015). Partisipasi Masyarakat Dalam Pengelolaan Sampah Di Lingkungan Margaluyu Kelurahan Cicurug. Share Social Work Jurnal5(1).

Sulistiyani, A. T \& Wulandari, Y. (2017). Proses Pemberdayaan Masyarakat Desa Sitimulyo, Kecamatan Piyungan, Kabupaten Bantul dalam Pembentukan Kelompok Pengelola Sampah Mandiri. Indonesian Journal of Community Engagement 2 (2).

Syam, D. M. (2014). Hubungan Pengetahuan dan Sikap Masyarakat Dengan Pengelolaan Sampah di Desa Loli Tasiburi Kecamatan Banawa Kabupaten Donggala. 21-26.

Yuliani 2017. Partisipasi Masyarakat Dalam Pengelolaan Hutan Mangrove Di Desa Segarajaya, Kecamatan Tarumajaya Kabupaten Bekasi. Vol 6 No 2: Jurnal Green Growth dan Manajemen Lingkungan. Hal 42 - 53 